\title{
Raman spectroscopy biochemical characterisation of bladder cancer cisplatin resistance regulated by FDFT1: a review
}

\author{
M. Kanmalar', Siti Fairus Abdul Sani ${ }^{*} \mathbb{0}$, Nur Izzahtul Nabilla B. Kamri ${ }^{1}$, Nur Akmarina B. M. Said ${ }^{2}$, \\ Amirah Hajirah B. A. Jamil², S. Kuppusamy ${ }^{3}$, K. S. Mun ${ }^{4}$ and D. A. Bradley ${ }^{5,6}$
}

\author{
${ }^{*}$ Correspondence: \\ s.fairus@um.edu.my \\ ${ }^{1}$ Department of Physics, \\ Faculty of Science, University \\ of Malaya, 50603 Kuala \\ Lumpur, Malaysia \\ Full list of author information \\ is available at the end of the \\ article
}

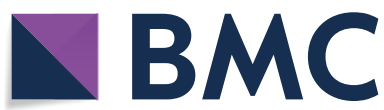

(O) The Author(s) 2022. Open Access This article is licensed under a Creative Commons Attribution 4.0 International License, which permits use, sharing, adaptation, distribution and reproduction in any medium or format, as long as you give appropriate credit to the original author(s) and the source, provide a link to the Creative Commons licence, and indicate if changes were made. The images or other third party material in this article are included in the article's Creative Commons licence, unless indicated otherwise in a credit line to the material. If material is not included in the article's Creative Commons licence and your intended use is not permitted by statutory regulation or exceeds the permitted use, you will need to obtain permission directly from the copyright holder. To view a copy of this licence, visit http:// creativecommons.org/licenses/by/4.0/.
Keywords: Bladder cancer, Diagnostic, FDFT1, Cisplatin chemoresistance, Raman spectroscopy

\section{Introduction}

Bladder cancer is one of the most prevalent urogenital malignancies [1], accounting for some 5 to $10 \%$ of total male malignancies worldwide, with a male-to-female ratio varying from 2: 1 to 6:1 in various regions [2]. Based on transurethral resections of bladder tumours (TURBT), approximately $70-80 \%$ of patients are diagnosed with non-muscle 
invasive bladder cancer (NMIBC), with a recurrence and progression rate to muscle invasive bladder cancer (MIBC) of 50-70\% [3]. The incidence of MIBC at first presentation is about $20 \%$. MIBC requires a more radical treatment approach that can contribute to increased morbidity and poorer overall survival. Treatment for MIBC generally involves radical cystectomy $(\mathrm{RC})$ with urinary diversion, representing the standard of care [4] with almost $50 \%$ of cases progressing to metastatic state within 2 to 3 years [5].

However, new data show improved overall survival with the use of cisplatin (cis-diamminedichloroplatinum [II])-based chemotherapy in a neoadjuvant setting followed by RC [6]. Bladder sparing methods are also advocated, using a combination of cisplatinbased chemotherapy and radiotherapy to avoid the morbidity associated with RC [7].

Cisplatin-based chemotherapy improves survival but may also be related to resistance and toxicity that may hinder capability to undergo $\mathrm{RC}$ or achieve benefit with radiotherapy. Resistance to cisplatin-based chemotherapy may mean it is not an option for patients who progress to metastatic state after radical treatment. There are currently no well-defined prognostic markers that can identify patients that are at high risk of developing resistance. A comprehensive understanding of patient subsets predicted to develop resistance towards cisplatin is essential to develop new therapeutic modalities.

Cholesterol is essential for cellular signals, including proliferation, and it is synthesised by virtually all tissues in the human body. The liver, intestine, adrenal cortex, and reproductive tissues give the largest contributions to the body's cholesterol pool. An imbalance in cholesterol regulation can lead to an elevation in circulating levels of plasma cholesterol, with the potential for the development of many cancers [8]. Cholesterol biosynthesis involves the mevalonate pathway. The upstream HMG-CoA pathway targeted by the drug simvastatin has shown to be a promising target to increase sensitivity towards doxorubicin in an in-vitro bladder cancer model [9]. Statin-induced reduction in intracellular cholesterol levels also has been shown to be correlated with inhibiting cancer cell line growth [10]. However, studies of the effect of cholesterol and the use of cholesterol-lowering approaches targeting HMG-CoA have given inconclusive results [11]. There is a need to elucidate the linchpin molecule that governs this process.

Chemoresistance and tumour progression may involve farnesyl-diphosphate farnesyltransferase 1 (FDFT1), a gene that encodes the membrane-associated enzyme squalene synthase, which is the first specific enzyme in cholesterol biosynthesis [12, 13]. However, its role in tumour progression is cancer-specific: FDFT1 has been implicated as a potential oncogene and as a tumour-suppressive gene in different types of cancer [14, 15]. In liver, lung, prostate, breast, ovary, bladder, cervix, thyroid, and esophageal cancers, FDFT1 is highly expressed, while in colorectal, colon, testicular, uterine, pancreas, and kidney tumours, its expression is downregulated [14-16]. In bladder cancer specifically, FDFT1 has been suggested as a predictive marker for drug sensitivity to chemotherapy compounds [17].

Other than the standard biopsy-staining approach, several groups have researched alternative techniques that may improve and/or enhance the diagnosis of bladder cancer [18]. These include fluorescent cystoscopy [19-21], electrical impedance spectroscopy [22], virtual cystoscopy with computed tomography (CT), and modulated resonance imaging (MRI) [23]. They can reduce time-consuming aspects of detecting tumour sites. Further to this, protein and DNA markers are used in urine analysis [24, 25], aiding in 
the detection of a tumour's presence and further supporting analyses of changes in tissue arrangement and configuration. In some techniques, the absence of contrast agents means that changes in composition and morphology cannot be localised.

The specificity and accuracy offered by Raman spectroscopy allows it to be employed as a non-invasive diagnostic tool for bladder cancer, providing for observation of pathogenesis and any biomolecular heterogeneity associated with cancer progression. Raman spectroscopy can also be applied in vivo during cystoscopy or in vitro to cells obtained from urine cytology samples.

The inelastic Raman scattering process concerns photons interacting at the molecular level, resulting in a shift in wavelength [26]. Examples of prior Raman spectrographic analyses in pathology have included examining for the existence of positives with dubious fluorescence [26]. The transmitted scattered photons result in the formation of a series of peaks, each characterising a molecular bond, providing a corresponding molecular fingerprint for a specimen [26]. Accordingly, Raman spectroscopy can assist in conjunction with other diagnostic strategies, providing user-friendly, real-time analysis. Current research focuses on the development of discriminatory cholesterol profiles via Raman spectroscopy, aimed at stratifying chemosensitivity status in bladder cancer tissues using this rapid and reagent-free tool.

\section{Bladder carcinoma}

Bladder cancer management depends on both the histotype and patients' risk factors. It is among the most costly cancers to treat, particularly in patients with advanced cancers [27]. There have been minor improvements in survival rates over the years [28], partly in response to treatment resistance. There have been multiple efforts in terms of early detection, better therapies, and survival improvement. Understanding the biology and molecular interplay underlying tumour progression and treatment failure supports the development of tools in the management of bladder cancer [29], specifically treatment response.

\section{Screening and diagnosing bladder cancer and treatment evaluation}

Cystoscopy (bladder endoscopy) is used in the advent of haematuria or voiding and storage symptoms, which are potential indicators of bladder cancer. Exfoliated urothelial cells from the urethra and voided urine are viewed using appropriate microscopy. When suspicious growth is identified during cystoscopy, TURBT is typically performed, providing a histopathological diagnosis.

Most bladder cancers are papillary, and some solid or mixed. Histopathological examination determines the bladder cancer subtype, grade, and tumour $(\mathrm{T})$ staging, and treatment decisions can be made based on this and other information. The most common subtype is transitional cell carcinoma, making up at least $90 \%$ of all bladder cancer subtypes. Other less common subtypes include those with squamous cell or glandular differentiation. The tumour is graded based on the WHO 2004/2016 Classification of Tumours of the Urinary System and Male Genital Organs [30], as low grade (LG), high grade (HG) or papillary urothelial neoplasm of low malignant potential (PUNLMP) based on the extent of cellular differentiation and anaplastic features. 
Staging of bladder cancer is based on the UICC TNM system of classification (2017), i.e., tumour $(\mathrm{T})$, node $(\mathrm{N})$, metastasis $(\mathrm{M})$, determining the pathological and clinical stage of the disease. The pathological assessment of the tumour provides information on the depth of invasion of the tumour $(\mathrm{T})$ in relation to the bladder, with evidence of infiltration of lamina propria, muscle, perivesical tissue and adjacent structures (Fig. 1). Based on the $\mathrm{T}$ stage of bladder cancer, the malignancy is broadly classified as non-muscle invasive (NMIBC) or muscle invasive (MIBC). Another important stage of bladder cancer is the presence of carcinoma in situ (CIS): a high-grade, non-invasive urothelial carcinoma that is deemed to be a significant lesion. This is often missed due to its flat appearance, which may mimic an inflammatory lesion. Lymph node $(\mathrm{N})$ status is also obtained from pathological assessment, which may indicate infiltration from specimens available from pelvic lymph node dissection during RC. However, in patients not undergoing radical surgery, staging would then rely on radiological imaging modalities, such as a CT scan to assess the lymph node and metastasis (M) status. This information, from tumour subtype, grade, clinical and pathological TNM staging, determines the treatment option. High-grade tumours are more likely to recur and progress as seen with MIBC patients, more than half of whom are at risk of developing metastasis.

\section{Treatment of bladder carcinoma}

Treatment of bladder cancer depends on risk stratification, which is vital information for enabling the clinician to estimate the probability of patients presenting with recurrence and the risk of progression. Factors taken into consideration include tumour staging, the presence of CIS, and the size and multiplicity of the lesions. The treatment for NMIBC is to surgically remove the lesion via TURBT, with the possibility of either supplementing the treatment with intravesical therapy using chemotherapy (mitomycin C) or intravesical immunotherapy using bacillus calmette-guerin (BCG). The use of BCG is usual in confirmed cases of HGT1 disease or when there is CIS in the resected specimen. These adjuvant intravesical therapies seek to reduce the risk of recurrence and progression to MIBC. This is followed by surveillance cystoscopy at regular intervals, looking for recurrence and progression.

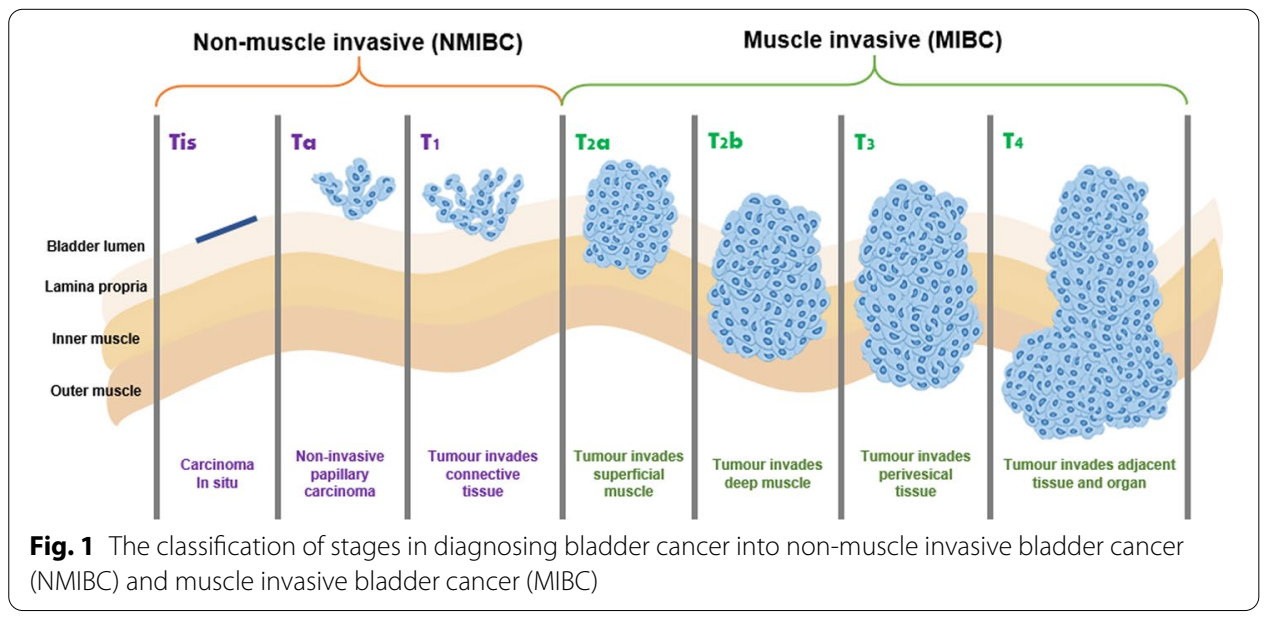


When a patient is diagnosed with MIBC, with the majority HG, the standard of care is to perform radical cystectomy with urinary diversion, including pelvic lymph node dissection. Current evidence and guidelines include the role of neoadjuvant cisplatin-based chemotherapy in viable practice. Counselling of patients is supported by an improved 10 -year overall survival of some $6 \%$ [31], with $16 \%$ reduction in the risk of mortality [32]. This is also a strategy to treat the possible micrometastasis present in the patient. The use of neoadjuvant chemotherapy also gives an indication as to whether the patient would respond to future adjuvant cisplatin-based chemotherapy if recurrence and progression of disease is identified in follow-up.

Adjuvant therapy is not indicated for treatment of MIBC after RC with or without neoadjuvant chemotherapy. In this regard, some patients will not accept losing the bladder and the need to cope with urinary diversion through use of a stoma, referred to as the ileal conduit. Thus, in management of lymph nodes, an alternative bladder sparing strategy could be considered, using cisplatin-based chemotherapy followed by radiotherapy. This should include local therapy, performing TURBT to ensure all of the lesion in the bladder is resected.

\section{Cisplatin-based chemotherapy in bladder cancer}

In bladder cancer, cisplatin is the backbone for chemotherapy regimens, either as a part of the methotrexate, vinblastine, adriamycin and cisplatin (MVAC) or gemcitabine and cisplatin (Gem-Cis) drug combinations. DNA is the main cellular target. As cisplatin diffuses into the cell, it reacts with the DNA strands. Then, the cisplatin will be activated after replacing its two chloride ligands with water molecules. Cellular death through activation of the apoptotic tract is the final consequence of cisplatin-mediated DNA damage.

However, cisplatin-based chemotherapy against bladder cancer is challenged by chemoresistance. The response rate towards this first line chemotherapy barely exceeds $50 \%$ [33] and patients who suffer recurrence after cisplatin-based chemotherapy are often resistant to second line chemotherapy, with a median progression-free survival (PFS) of 3-4 months [34]. Therefore, patients would likely benefit from a predictive test that can be performed on the biopsy sample taken during diagnosis or TURBT. A comprehensive clinical and molecular understanding of emerging pathways in chemoresistance is thus fundamentally essential in developing the predictive marker.

Bladder cancer cells have been shown to develop resistance towards cisplatin via various mechanisms, including drug inactivation, drug target alteration, drug efflux, DNA damage repair, cell death inhibition and the epithelial-mesenchymal transition (EMT) [33]. Recently, an impaired cholesterol metabolism has been shown to be one of the most important mechanisms regulating the cellular response towards chemotherapy [35].

\section{Role of abnormal cholesterol metabolism and FDFT1 in tumour progression and chemoresistance}

Cholesterol is an essential component of the cellular membrane. Distributed between hydrocarbon chains, it plays a pivotal role during membrane assembly and in the stability, architecture, dynamics, and function of the plasma cell membrane. It also modulates transmembrane receptor signalling, is involved in vesicle trafficking, and serves 
as the precursor of steroid hormones and sterols during steroidogenesis [36, 37]. Thus, cholesterol moderates multiple biological responses and regulates various cellular functions, including membrane biogenesis, cell growth, proliferation, apoptosis, and migration [38, 39], and is increasingly implicated in carcinogenesis and chemoresistance [39, 41-43]. Here, we briefly review how cholesterol is synthesised, how cancer cells reprogram cholesterol metabolism to promote carcinogenesis and treatment resistance to chemotherapy $[8,39,40]$, and the emerging role of FDFT1 in tumour progression and chemoresistance.

\section{Overview of cholesterol metabolism}

Approximately half of the cholesterol in the body is derived from de novo biosynthesis. Every mammalian cell can synthesise cholesterol, although the liver, intestine, adrenal cortex, and reproductive tissues (including the ovaries, testes, and placenta) make the largest contributions to the body's cholesterol pool. Biosynthesis in the liver accounts for approximately $10 \%$, and in the intestines approximately $15 \%$ of the amount produced each day. Cholesterol is a 27-carbon and tetracyclic ring steroid catalysed by a series of more than 26 separate enzymatic reactions in several subcellular compartments [37, 44, 45]. The process of cholesterol synthesis is comprised of several major steps as depicted in Fig. 2.

Apart from de novo cholesterol biosynthesis, most cells can also acquire cholesterol from low-density lipoprotein (LDL) taken up from the circulation via LDL receptormediated (LDLR-mediated) endocytosis. Enterocytes absorb dietary cholesterol from the intestinal lumen via cholesterol transporters, the clathrin adaptor, and the adaptor protein [46, 47]. Within the cell, cholesterol is dynamically transported to its destination membranes, where it fulfills structural and functional needs. Cholesterol that exceeds cellular demand is either exported from the cell by ATP-binding cassette (ABC) transporters, converted to less toxic cholesteryl esters (CEs) by acyl-coenzyme cholesterol acyltransferases (ACATs) and stored in lipid droplets, or secreted within lipoproteins [48].

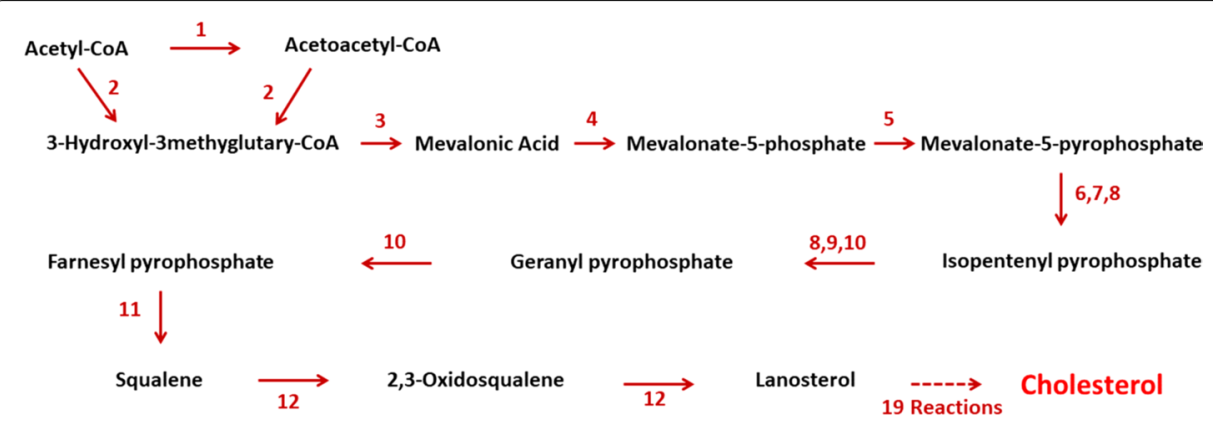

Fig. 2 The cholesterol biosynthesis pathway. (1) Thiolases or acetyl-coenzyme A acetyltransferases, (2) hydroxy-3-methylglutaryl-CoA synthase, (3) hydroxy-3-methylglutaryl-CoA reductase, (4) mevalonate-3-kinase or me-valonate-5-kinase, (5) mevalonate-3-phosphate-5-kinase or phosphomevalonate kinase, (6) mevalonate-5-phosphate decarboxylase, (7) mevalonate pyrophosphate decarboxylase, (8) isopentenyl phosphate kinase, (9) isopentenyl pyrophosphate isomerase, (10) farnesyl-diphosphate synthase, (11) squalene synthase, or FDFT1, (12) squalene monooxygenase or squalene epoxidase. There are 19 reactions, including multiple demethylations, desaturations, isomerizations, and reductions [44] 
Cholesterol concentrations at both the cellular and systemic levels are maintained with fine-tuned regulations. The master transcriptional regulators governing cholesterol homeostasis include sterol regulatory element-binding protein-2 (SREBP-2), liver X receptors (LXRs) and nuclear factor erythroid 2 related factor-1 (NRF1) [49]. Accumulation of cholesterol and cholesterol-derived oxysterols inactivates the SREBP-2 pathway, thereby downregulating cholesterol biosynthesis and uptake. In addition, desmosterol, the immediate precursor of cholesterol and oxysterols, binds and activates LXRs, thereby enhancing the expression of genes involved in cholesterol efflux, such as the ATP-binding cassette subfamily A member 1 (ABCA1) [50]. These regulatory pathways function in a coordinated and opposing manner under conditions of cholesterol deficiency, ensuring an increase in cholesterol biosynthesis and uptake as well as a decline in cholesterol efflux and esterification.

\section{Reprogrammed cholesterol metabolism in cancer cells}

Reprogrammed lipid metabolism is now established as a hallmark of cancer, with accelerated cholesterol metabolism increasingly associated with many types of cancer $[8$, 39, 40]. Cancer cells require excess cholesterol and intermediates of the cholesterol biosynthetic pathway to maintain accelerated levels of cell growth and proliferation. Cholesterol is also capable of regulating multiple signalling pathways involved in carcinogenesis, cancer cell migration, and tumour progression, but it has also recently been strongly associated with chemoresistance [39, 41-43]. Indeed, transformed cells reprogram cholesterol metabolism by increasing its uptake and de novo biosynthesis, or by deregulating its efflux.

The master transcription factor SREBP2 and its downstream targets, including mevalonate pathway enzymes, are significantly upregulated in various tumours [51]. This can be accompanied by increased levels of the enzyme SQLE, for example in advanced-stage prostate cancer, indicating a greater reliance on cholesterol synthesis [52]. Cholesterol biosynthesis also has a critical role in maintaining cancer stem cells: it activates cellular signalling pathways downstream of hedgehog, notch and receptor tyrosine kinases [53]. Increased cholesterol uptake is also observed in cancer cells. As an example, anaplastic large cell lymphoma cells fully rely on cholesterol uptake to acquire cholesterol. They actively upregulate LDLR, which takes up exogenous cholesterol as an alternative strategy to support proliferation [55].

The mevalonate pathway has also been implicated in oncogenic pathways, with gain of oncogenes also corresponding with fluctuations in cholesterol biosynthesis, while tumour suppressors antagonise this overactivated state and maintain cholesterol homeostasis. For example, activation of Akt has been shown to cause the upregulation of SREBP and its target genes in the cholesterol pathway, suggesting a positive correlation between oncogene activation and cholesterol metabolism [56]. The oncogene MYC has also been shown to be responsible for upregulation of the mevalonate pathway in patient-derived brain tumour-initiating cells [57]. The tumour suppressor p53 upregulates the cholesterol efflux transporter ABCA1, thereby restricting SREBP2 maturation and subsequently repressing the mevalonate pathway. In prostate cancer [59] and hepatocellular carcinoma [60], the loss of the tumour suppressor phosphatase and 
tensin homolog (PTEN) activates PI3K-Akt signaling and leads to increased cholesterol uptake, facilitating cancer progression.

Increased resistance to apoptotic signals was also reportedly linked to high mitochondrial cholesterol in a few types of cancer. Proteins such as STAR and STARD3, which are responsible for initiating the transportation of cholesterol to the mitochondria, were shown to be associated with increased cancer cell proliferation and a decreased therapeutic response to chemotherapy in breast cancer cells [61]. Numerous reports suggest that an alteration in cholesterol metabolism contributes to the ineffectiveness of various cancer therapies. An increase in the mitochondrial cholesterol level also causes chemoresistance in hepatocellular carcinoma by increasing the expression of P-glycoprotein (P-gp) through PI3K/mTOR signaling, thereby diminishing the efficacy of doxorubicin [62]. High cholesterol content hampers the sensitivity of paclitaxel and cisplatin through upregulation of the drug efflux pumps, along with an increase in cholesterol receptor $(\mathrm{LXRa} / \beta)$ expression [63]. A similar observation was reported in lung adenocarcinoma where pre-treatment or co-treatment of cholesterol with carboplatin decreased the cytotoxic potential of these drugs in A549 cells [64].

It is evident that deregulated cholesterol metabolism promotes tumour progression and hampers treatment strategies in various cancers. Understanding the mechanistic role of cholesterol in bladder cancer carcinogenesis and the therapeutic implications is an emerging research topic. Recent studies reported the oncogenic roles of the cholesterol metabolite 25-hydroxycholesterol in bladder cancer and promoted chemoresistance in T24 and RT4 bladder cancer cells [65]. Therefore, improved understanding on the regulation of cholesterol metabolism has important implications for exploring new therapeutic strategies for the management and treatment of bladder cancer.

\section{Role of FDFT1 in cancer progression and chemoresistance}

FDFT1 is a gene that encodes the membrane-associated enzyme squalene synthase, which is the first specific enzyme in cholesterol biosynthesis that is increasingly implicated in tumour progression and the development of therapeutic resistance to anticancer drugs. Cholesterol biosynthesis pathways include branches producing sterol and non-sterol isoprenoids. FDFT1 has a critical regulatory role, as the specific enzyme in the sterol branch catalyses the conversion of farnesyl diphosphate (FPP) into squalene, leading to the synthesis of cholesterol. As the FPP is located at the end of the biosynthesis cycle of isoprenoid, its modification into squalene catalysed by FDFT1 action is the first stage of cholesterol biosynthesis, making it an obvious target for therapeutic intervention [66]. Of cellular and molecular importance in the mevalonate pathway is the prenylation of isoprenoids. This important post-translational modification along with activation of regulatory proteins, such as G-proteins, Ras, and p21, is essential for intracellular signalling and cell growth [15].

In prostate cancer cell lines, inhibiting FDFT1 has been shown to inhibit cell proliferation. FDFT1 transcript levels have been found to be significantly greater in prostate cancer tissues than in benign tissues, and higher in very aggressive cancers than in those that are moderately aggressive [14]. These findings in prostate cancer may be attributed to the androgen regulation of FDFT1 [16]. 
In contrast to these findings, FDFT1 is identified as a tumour suppressor gene in the bladder cancer model. Apart from being highly expressed in cisplatin-sensitive bladder cancer cell lines compared to its resistant counterpart, knockdown of FDFT1 in bladder cancer cells has resulted in acquisition of mesenchymal morphology and increased vimentin expression [12]. Indeed, FDFT1 has been shown to be overexpressed in superficial bladder cancer samples compared to muscle invasive bladder carcinoma [13]. This could be partly explained by the role of FDFT1 in directing the FPP substrate towards sterol and non-steroid branches. In tumours where FDFT1 is downregulated, isoprenoids can accumulate, providing more substrate for protein prenylation, causing uncontrolled cell growth.

Interestingly, FDFT1 is also among the top $10 \%$ genes overexpressed in bladder cancers that are sensitive to the anti-tumour drugs vandetanib and tipifarnib $[17,67]$ and in esophageal cancer cell lines that are sensitive to docetaxel, paclitaxel, and doxorubicin [68]. FDFT1 is also among the top $1 \%$ of genes with copy number gain in multiple cancer cell lines that are sensitive to panobinostat [67]. All these data suggest the role of FDFT1 in conferring sensitivity towards chemotherapy, and its potential as a predictive marker for drug sensitivity. As such, cholesterol- and FDFT1-associated biochemical characterisation might aid the prediction of chemosensitivity in bladder cancer patients. This can be achieved using Raman spectroscopy, making it a feasible complementary predictive tool.

\section{Raman spectroscopy}

Due to the attainability of molecular fingerprints, vibrational spectroscopy has become a remarkable technique to analyze substances at the molecular level. Raman spectroscopy, as a vibrational spectroscopy, enables the determination and characterization of the chemical properties of a material. Besides identifying the presence of molecules, Raman spectroscopy can examine the intramolecular bonds and deliver quantified results by allowing the determination of the vibrational frequencies of the chemical bonds. It is undeniable that the advantageous output of Raman spectroscopy has attracted major interest in industries such as geology, mineralogy and electronic fields, but due to the accessibility of Raman spectroscopy ex vivo and in vivo it is also widely used for research in describing biomedical complications [69]. This mechanism is used extensively to diagnose disease as it can discriminate diseased tissues from healthy tissues based on biomolecular changes. Recent diagnostic studies on Alzheimer's disease [70], bacterial infection such as typhoid and tuberculosis [71], and cardiovascular disease [72] demonstrated the promising capability of Raman spectroscopy for early detection.

\section{Mechanism of Raman spectroscopy}

The analytical method referred to as Raman spectroscopy is based on the inelastic scattering of incident monochromatic light by molecules within specimens. Elastic scattering, referred to as Rayleigh scattering, contrasts with this. The shift in energy from incident light differentiates Raman from Rayleigh scattering, but Rayleigh scattering dominates over the former. Although only 1 in $10^{7}$ photons subjected to Raman inelastic scattering [73], it is nevertheless a powerful technique. 
The interaction of incident light with the molecular bonds in the material leads to molecules transitioning from one vibrational energy state to another. Then, the molecules relax and de-excite to a final vibrational energy state via radiative transitions, emitting scattered photons. The energy of the scattered photon is the difference between the energy of the initial and final vibrational states, with the energy of the scattered photons being unique to specific molecular bonds. The loss or gain in energy, the respective stoke or anti-stoke process, are the two possibilities resulting from Raman scattering. Stoke is the more intense of the two due to the natural existence of a greater number of ground state molecules compared to those in an excited state [74].

\section{Raman spectrum and vibrations of chemical bonds}

The Raman spectrum is a plot of the intensity of emitted photons against the Raman shift, determined as a shift in inverse wavelength and expressed with units of inverse length. The quantity, conventionally referred to as wavenumber, gives a direct link to energy. Chemical bonds offer specific vibrations and manifest as peaks in the Raman spectrum. The vibrations associated with chemical bonds can be divided into two groups: stretching and bending [75]. These two groups are further subdivided into more classes as depicted in Fig. 3. It is noticeable that these groups are bond length and angle dependent, where the bond length changes in stretching vibrations and angulations of the bands of wavelength become unstable in bending vibrations. The vibrations are correlated to specific molecular bonds, giving the biochemical fingerprints of the specimen. The symbolic representations of the respective types of vibrations are shown in Table 1.

\section{Raman spectrometer}

The construction of the Raman spectrometer relies on a monochromatic laser as the source of excitation. When supported by a light guidance system that incorporates lenses, mirrors and a diffraction grating to determine the pathway of the laser and scattered photons, this allows investigation of the sample with minimum power loss.

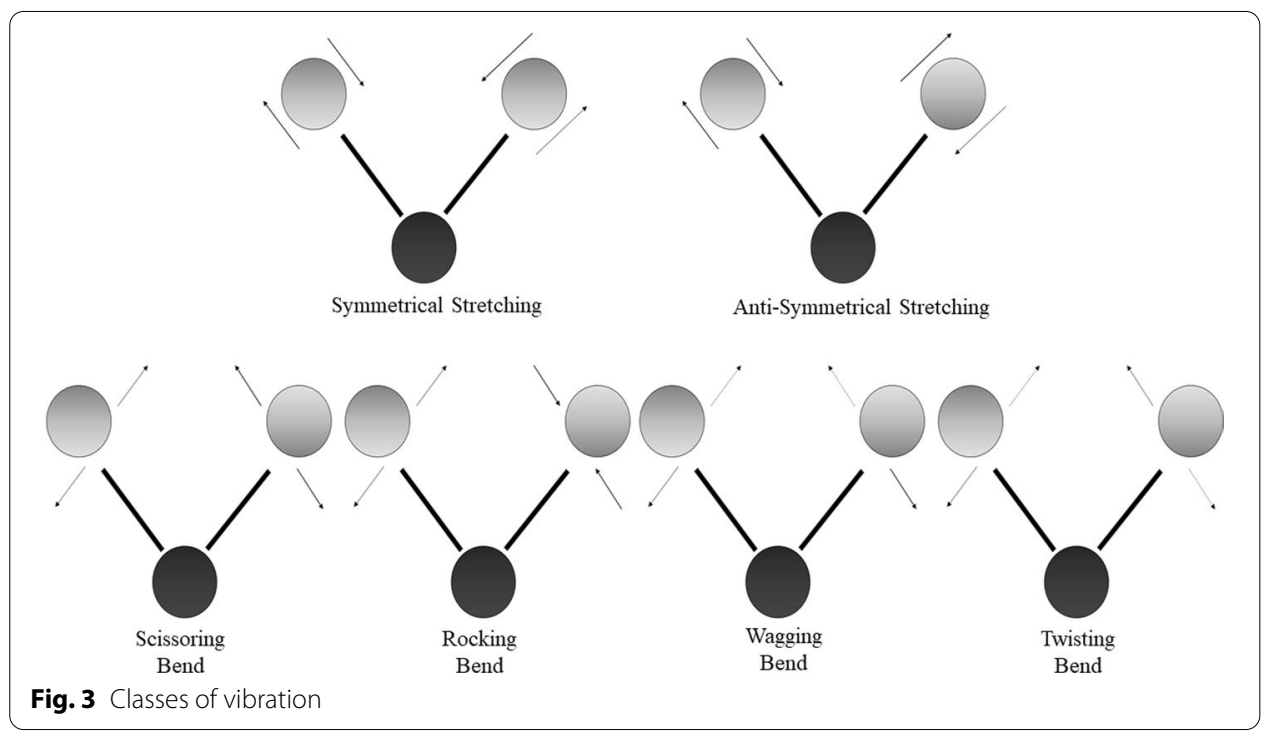


Table 1 Symbols used to identify the sub-classes of vibrations

\begin{tabular}{ll}
\hline Symbol & Name of vibration \\
\hline$v$ & Stretch \\
vs & Symmetric stretch \\
vas & Asymmetric stretch \\
$\delta$ & Deformation/bend- \\
$\rho$ & ing/scissoring \\
$\tau$ & Rock \\
$\omega$ & Torsion \\
$\omega i$ & Wag \\
wo & In-plane wag \\
t & Out-of-plane wag \\
\hline
\end{tabular}

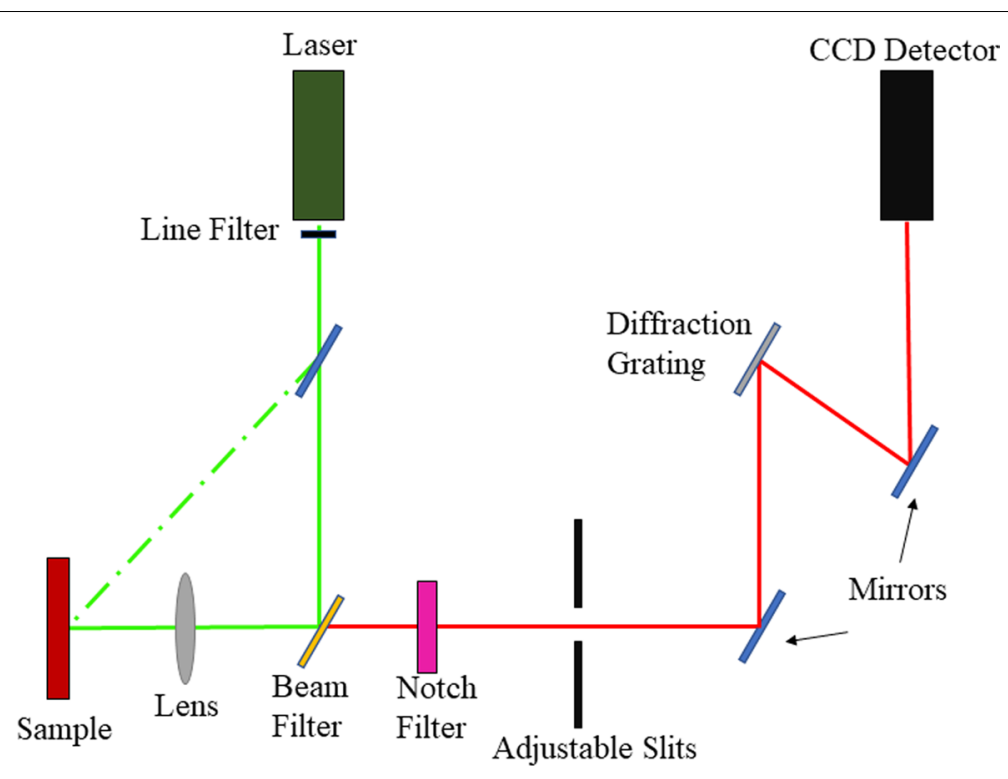

Fig. 4 The basic components in a conventional Raman spectrometer

Identification at the detector is in accordance with the wavelength. The presence of a notch filter is essential as it enhances the collection of Raman scattering and excludes the Rayleigh scattered photons emitted by the sample. A charge-coupled device (CCD) detector is typical, recording the signal and connecting to a computer system for data interpretation [76]. Figure 4 shows the schematic setup of a conventional Raman spectrometer. Various upgrades are available to better support the analysis of biological samples. For example, Raman microspectroscopy allows a conventional spectrometer to be embedded with a microscope to provide confocal capability [77]. Another advance is the Raman probe, an innovation allowing adaptation for in vivo studies [78].

\section{Raman spectroscopy in diagnosing bladder cancer}

The implementation of Raman spectroscopy as an optical diagnostic tool for bladder cancer research offers various interesting opportunities. A major drawback of 
current cancer diagnostic tools is the inability to analyse the tumour at the cellular level. Most present-day techniques simply deliver information on the presence and location of the tumour. This inability is resolved by harnessing the power of Raman spectroscopy, providing minutiae of the molecular composition of the tissue and enabling the detection of biomolecular changes in the cells associated with tumour development. Accordingly, the remainder of this section seeks to give an outline summary of the determination of metabolic changes in bladder cancer cells, focusing on Raman spectroscopy studies conducted over the past decade.

\section{Metabolite changes in bladder cancer}

There is a clear trend in the determination of biomolecule changes in bladder cancer, with differentiation of healthy cells from cancer tissue, distinguishing high-grade bladder cancer tissue from low-grade cancer tissue. A summary of developments is provided in Additional file 1: Table S1, which consists of a list of observed Raman peaks with the corresponding assignments indicating the biomolecules and the vibrations of the functional group. The specific value of the intensity is not provided in the literature, and it is notable that the level of intensity is different for each study. However, the comparison of the intensity level, which is the indication of expression and concentration of metabolites, between the samples of healthy tissues, low-grade tumours and high-grade tumours enables us to differentiate the grading of bladder tumours.

There are various trends in terms of abnormalities of the metabolites found in cancer cells. It is evident that the concentrations of bio-substances, such as carbohydrates ( $\mathrm{C}-\mathrm{C}-\mathrm{C}$ deformation), tryptophan (symmetric breathing), collagen, nucleic acid of DNA, protein/lipid $\left(\mathrm{CH}_{2}\right.$ bending), fatty acid, amide I, triglyceride, and phenylalanine/tryptophan $\left(\mathrm{C}-\mathrm{C}_{6} \mathrm{H}_{5}\right)$ are greater in healthy tissue and lower in high-grade versus low-grade tumours. Furthermore, high-grade tumours have been reported to show overexpression of L-arginine, amide VI, L-tyrosine, phospholipid, $\mathrm{D}$-mannos and $\alpha$-helix protein compared to healthy tissue and low-grade tumours. Conversely, the metabolites phenylalanine ( $\mathrm{C}-\mathrm{C}$ vibration and twisting), DNA base, tyrosine, lipid $\left(\mathrm{CH}_{3}, \mathrm{CH}_{2}\right.$ twisting) and the $\mathrm{CH}_{3}, \mathrm{CH}_{2}$ bonds of tryptophan, adenine and guanine show greater intensities in high-grade tumours, and are also decreased in normal tissue compared to low-grade tumours.

Moreover, an interesting pattern is identified wherein peaks not found in one group of tissue are detected at high intensity in other groups. For instance, for the Raman peaks of cholesterol and its esters, cytochromes and unsaturated fatty acids are more upregulated in low-grade tumours than in normal tissue, while they are absent in high-grade tumours. By contrast, olenic starch $(\mathrm{C}=\mathrm{C})$ appears in both low- and high-grade tumours but is not found in normal tissue. Accordingly, the establishment of Raman peaks as recognized in previous studies points to ways to differentiate normal bladder tissues from cancerous tissues and in classifying the grade of the tumour. Implementation of Raman spectroscopy is thus driving towards more detailed investigations of bladder cancer, observing the constitution of biocomponents at the molecular level. 


\section{Sensitivity and specificity of Raman spectroscopy in bladder cancer studies}

Acceptance and employment of any diagnostic technique is strongly dependent upon the proffered sensitivity and specificity. In a medical context, sensitivity refers to the percentage of cases for which classification of a specific health condition is correct. Conversely, specificity refers to the percentage of cases producing correct negative signatures for a given health condition [85]. These two aspects are focal to successful diagnostic laboratory testing: the greater the percentages, the greater the efficiency of the device. Raman spectroscopy has been demonstrated to perform well. Table 2 provides a summary of the performance of Raman spectroscopy in categorizing healthy tissue versus low- and high-grade bladder cancer.

The assessments for studies made over the past decade were conducted with various samples, Raman spectroscopy instrumentations and analysis techniques. In discriminating bladder cancer from healthy tissue and supported by principal component and linear discriminant analysis (PCA and LDA), Draga et al. reported the in vivo use of a portable Raman spectroscopy system [83], obtaining respective sensitivity and specificity values of 85 of and 79\%. Likewise supported by PCA, Shapiro et al. applied Raman molecular imaging technology in the investigation of urine samples, obtaining respective sensitivity and specificity values of 92 and 91\% [84]. Canetta adopted the same analysis technique and introduced a modulated Raman spectrometer in differentiating normal from cancerous bladder tissues, with $98 \%$ sensitivity and $95 \%$ specificity [86]. Using surfaceenhanced Raman spectroscopy (SERS), Li et al. investigated blood serum, adopting two types of analysis technique in classifying healthy versus cancerous bladder tissue [87]. In the use of PCA, respective sensitivity and specificity values of 74.6 and $97.2 \%$ were obtained. Using a generic algorithm (GE) combined with LDA, respective values of 90.9

Table 2 Assessment of recent studies in the diagnosis bladder cancer (BC) in terms of the sensitivity and specificity provided by Raman spectroscopy

\begin{tabular}{|c|c|c|c|c|c|c|c|}
\hline \multirow[t]{2}{*}{$\begin{array}{l}\text { Type of } \\
\text { sample }\end{array}$} & \multirow{2}{*}{$\begin{array}{l}\text { Raman } \\
\text { spectrocopy } \\
\text { instrumentation }\end{array}$} & \multirow[t]{2}{*}{$\begin{array}{l}\text { Analysis } \\
\text { technique }\end{array}$} & \multicolumn{2}{|c|}{$\begin{array}{l}\text { Healthy vs. bladder } \\
\text { cancer }\end{array}$} & \multicolumn{2}{|c|}{$\begin{array}{l}\text { High-grade } B C \text { vs. low- } \\
\text { grade } B C\end{array}$} & \multirow[t]{2}{*}{ References } \\
\hline & & & $\begin{array}{l}\text { Sensitivity } \\
(\%)\end{array}$ & $\begin{array}{l}\text { Specificity } \\
(\%)\end{array}$ & $\begin{array}{l}\text { Sensitivity } \\
(\%)\end{array}$ & $\begin{array}{l}\text { Specificity } \\
(\%)\end{array}$ & \\
\hline $\begin{array}{l}\text { Tissue } \\
\text { sample }\end{array}$ & $\begin{array}{l}\text { Portable Raman } \\
\text { spectrometer }\end{array}$ & $P C A+L D A$ & 85 & 79 & - & - & [83] \\
\hline $\begin{array}{l}\text { Urine } \\
\text { sample }\end{array}$ & $\begin{array}{l}\text { Raman micro- } \\
\text { scope }\end{array}$ & PCA & 92 & 91 & - & - & {$[84]$} \\
\hline $\begin{array}{l}\text { Tissue } \\
\text { sample }\end{array}$ & $\begin{array}{l}\text { Modulated Raman } \\
\text { spectrometer }\end{array}$ & PCA & 98 & 95 & - & - & [86] \\
\hline \multirow{2}{*}{$\begin{array}{l}\text { Blood } \\
\text { serum }\end{array}$} & \multirow{2}{*}{$\begin{array}{l}\text { Surface enhanced } \\
\text { Raman spectros- } \\
\text { copy }\end{array}$} & $G E+L D A$ & 90.9 & 100 & & - & \multirow[t]{2}{*}{ [87] } \\
\hline & & PCA & 74.6 & 97.2 & - & - & \\
\hline $\begin{array}{l}\text { Blood } \\
\text { serum }\end{array}$ & $\begin{array}{l}\text { Surface enhanced } \\
\text { Raman spectros- } \\
\text { copy }\end{array}$ & $\mathrm{SVM}+\mathrm{RBF}$ & - & - & 92.3 & 98.2 & {$[80]$} \\
\hline $\begin{array}{l}\text { Tissue } \\
\text { sample }\end{array}$ & $\begin{array}{l}\text { Raman micro- } \\
\text { scope }\end{array}$ & $P C A+k N N$ & - & - & 99 & 87 & {$[88]$} \\
\hline $\begin{array}{l}\text { Blood } \\
\text { serum }\end{array}$ & $\begin{array}{l}\text { Surface enhanced } \\
\text { Raman spectros- } \\
\text { copy }\end{array}$ & PLS + LDA & 98.3 & 96.7 & 90.6 & 96.3 & {$[81]$} \\
\hline
\end{tabular}

PCA principal component analysis, LDA linear discriminant analysis, GE generic algorithm, SVM support vector machine algorithm, $R B F$ radial basis function analysis, $k N N \mathrm{k}$ nearest neighbor classification analysis 
and $100 \%$ were attained. Zhang et al. were able to identify high- and low-grade bladder tumours using blood serum and SERS [80]. They developed a classifier model from the support vector machine (SVM) algorithm, which allows spectral data classification and regression, combined with radial basis function (RBF), helped in yielding 92.3\% sensitivity and $98.2 \%$ specificity. Bovenkamp et al. used a Raman microscope to examine bladder tissue, such that with the aid of a combination of PCA and k nearest neighbor classification analysis $(\mathrm{kNN})$, high- and low-grade bladder tumours could be discriminated with 99 and $87 \%$ sensitivity and specificity, respectively [88]. Chen et al. successfully discerned normal bladder from cancerous tissue and high- from low-grade bladder cancer with respectivesensitivities and specificities of 98.3 and $96.7 \%$, and 90.6 and $96.3 \%$ [81].

\section{Independency of Raman spectroscopy on sample type}

Additional file 1: Tables S1 and S3 clearly show that researchers verified the application of Raman spectroscopy on different biological sources in diagnosing bladder cancer. With respect to the specification mentioned, Kujdowicz et al. employed cultured cell lines of healthy bladder, low-grade and high-grade bladder cancer in their studies [79]. A portable Raman spectroscopy system is used by Draga et al. to perform the spectroscopy on the bladder lesion [83]. The achievement in discriminating the healthy bladder tissue, low-grade and high-grade bladder cancers from each other shows the aptitude of Raman spectroscopy in performing both in vitro and in vivo procedures. Several successful attempts can be found in conducting the Raman spectroscopy on samples that are discrete in types, such as tissue samples, urine samples and blood serum. Demonstrating high sensitivity and specificity and with no discernible dependence on sample type, Raman spectroscopy is seen as a promising diagnostic candidate for bladder cancer examination, with various analysis techniques and spectrometer setups enhancing the efficiency.

\section{Expected metabolites changes associated to FDFT1 in regulating chemoresistance}

For cancer diagnosis via Raman spectroscopy, it is apparent that the biochemicals found in samples are rather large in range, varying with cancer tissue type and cancer cell and further involving the microenvironment of the cells and associations with the nucleus or cytoplasm. It should be noted that the samples are prepared via use of a cystoscope, embedded into microscope slides, and with FDFT1 staining performed by pathologists. In inspecting the chemoresistance exhibited by cancerous bladder tissue regulated by FDFT1, there are certain metabolites that are the focus of this study with Raman peak assignments for each.

In respect to the cholesterol biosynthesis pathway, the FDFT1 enzyme plays a key role in producing the squalene that leads to the opening up of the sterol branch leading to the eventual synthesis of cholesterol. Squalene, the direct product of FDFT1, can thus be expected in the FDFT1 samples extracted from the bladder. Furthermore, cholesterol is the end-product regulated by FDFT1, being found in almost all parts of the human body. It needs to be considered that the cholesterol regulated by FDFT1 has been found to influence the chemoresistance exerted by cancerous cells. Accordingly, the detection of trends in changes in cholesterol expression can be anticipated to lead to insights in understanding bladder cancer. In addition, activities occurring in the microenvironment 
of cancerous cells regulate the resistance towards cisplatin, where acceptance and rejection of the drug is mainly by the cell membrane. Hence, as it is the main biocompound of the phospholipid bilayer in exerting cell signaling and with association with cholesterol, unsaturated fatty acid is also predicted to be found in FDFT1 compounds.

The type of bonds present in the metabolites are listed in Additional file 1: Table S2 and the symbolic meanings connected to the Raman peak assignment vibrations are in Table 1. The Raman peak assignment for all three metabolites (squalene, cholesterol and unsaturated fatty acid) are listed in Additional file 1: Tables S3-S5 respectively, while Additional file 1: Figs. S1-S3 depict the chemical structures of the metabolites and the types of molecular bond that have been determined. The presence of other components in FDFT1 are to be anticipated, potentially leading to greater understanding of the chemoresistance exerted by bladder cancer.

\section{Conclusion}

Bladder cancer is a critical metastatic disease marked by a high rate of recurrence and poor overcall survival. To treat and control muscle invasive bladder cancers, cisplatinbased chemotherapy has become a favoured approach, offering the ability to alter the DNA of cancer cells. However, it has also been found that cancer cells can exhibit resistance towards chemotherapeutics, posing a threat to the effectiveness of cisplatin-based chemotherapy. Evidence reviewed herein indicates that biosynthesis of the intracellular cholesterol has the tendency inexerting resistance towards cancer treatments. Conversely, molecular studies have indicated that chemosensitivity in bladder cancer cells correlates with FDFT1 expression: the first key specific enzyme in intracellular cholesterol biosynthesis.

Using Raman Spectroscopy, this biochemical property could potentially be developed into a diagnostic or predictive tool to stratify patients with a high risk of developing resistance. Although cancer diagnostic technique have evolved, the inadequacy of contemporary diagnostic tools in inspecting the microenvironment of the cancerous cells can be overcome using Raman spectroscopy. This technique is proposed in current research as it provides information on biomolecular changes in tissue, detecting molecular bonds, often obtained with the high specificity and sensitivity that is vital for a diagnostic tool. The feasibility of this technique in analyzing biological specimens in solid, liquid, gases and gel forms indicates the lack of need for special sample preparation. Besides being accessible for both in vivo and in vitro measurements, enhancements in determining and differentiating the medical peculiarities from healthy conditions using Raman spectroscopy with the accommodation of signal processing techniques, has become a particularly strong advantage. Upregulated FDFT1 expression in cancer cells made changes in cholesterol biosynthesis and altered the cholesterol content of lipid rafts. Therefore, rapid multiplication and high survival rates occur in cancer cells. Thus, this project hypothesizes the Raman spectroscopy detection of high concentration of metabolites correlated to FDFT1 in chemoresistant bladder cancer tissue. The outcome will be significant biomarkers to differentiate chemoresistant from chemosensitive bladder tumours, which can be applied for further diagnosis and treatment procedures. 


\section{Abbreviations}

TURBT:Transurethral resection of bladder tumour; BC: Bladder cancer; NMIBC: Non-muscle invasive bladder cancer; MIBC: Muscle invasive bladder cancer; RC: Radical cystectomy; FDFT1: Farnesyl diphosphate farnesyltransferase 1; CT: Computed tomography; MRI: Modulated resonance imaging; LG: Low-grade; HG: High-grade; PUNLMP: Papillary urothelial neoplasm of low malignant potential; TNM: Tumour, node, metastasis; CIS: Carcinoma in situ; BCG: Bacillus Calmette Guerin; MVAC: Methotrexate, vinblastine, adriamycin, cisplatin; PFS: Progression-free survival; EMT: Epithelial-mesenchymal transition; LDL: Low-density lipoprotein; LDLR: Low-density lipoprotein receptor; ABC: ATP-binding cassette; CE: Cholesterol esters; ACAT: Acyl-coenzyme cholesterol acyltransferase; SREBP-2: Sterol regulatory element-binding protein-2; LXR: Liver X receptor; NRF1: Nuclear factor erythroid 2 related factor 1; ABCA: ATP-binding cassette subfamily A member 1; PTEN: Phosphatase and tensin homolog; FPP: Farnesyl diphosphate; CCD: Charge coupled device; PCA: Principal component analysis; LDA: Linear discriminant analysis; GE: Generic algorithm; SVM: Support vector machine; RBF: Radial basis function analysis; kNN: K nearest neighbour classification analysis; SERS: Surface enhanced Raman spectroscopy.

\section{Supplementary Information}

The online version contains supplementary material available at https://doi.org/10.1186/s11658-022-00307-x.

Additional file 1: Table S1. Raman peak assignments obtained from healthy bladder, low-grade bladder tumour and high-grade bladder tumour with symbols indicating, '/': a peak with low intensity, '//': a peak with greater intensity than '/' but lower than '///' and'///': peak of high intensity. 'X' refers to the absence of the peak. Table S2. Molecular bonds denoted in Figs. S1 to S3. Table S3. Raman peak assignment for squalene. Figure S1. Chemical structure of squalene. Table S4. Raman peak assignment for cholesterol and its esters. Figure S2. Chemical structure of cholesterol. Table S5. Raman peak assignment for unsaturated fatty acid. Figure S3. Chemical structure of unsaturated fatty acids.

\section{Acknowledgements}

We acknowledge financial support from the University of Malaya (UM), providing a grant under the Impact-Oriented Interdisciplinary Research Grant Programme (IIRG) (IIRG022B-2019).

\section{Authors' contributions}

MK collected the review journals and wrote the manuscript. ASSF reviewed and supervised the whole process of writing the manuscript. NINBK supported in collecting the data related to the studies. NABMS, AHBAJ, SK, KSM supported the investigation of the biomedical facts behind bladder cancer and contributed to the manuscript. DAB contributed to the final version of the manuscript. All authors read and approved the final manuscript.

\section{Funding}

Impact Oriented Interdisciplinary Research Grant Programme (IIRG; IIRG022B-2019) from the University of Malaya.

Availability of data and materials

All data analysed during this study are included in the published articles and books listed in the References list [1-95].

\section{Declarations}

Ethics approval and consent to participate

Not applicable.

\section{Consent for publication}

Not applicable.

\section{Competing interests}

The authors declare that they have no competing interests.

\section{Author details}

'Department of Physics, Faculty of Science, University of Malaya, 50603 Kuala Lumpur, Malaysia. ${ }^{2}$ Department of Pharmaceutical Life Sciences, Faculty of Pharmacy, University of Malaya, 50603 Kuala Lumpur, Malaysia. ${ }^{3}$ Department of Surgery, University of Malaya, 50603 Kuala Lumpur, Malaysia. ${ }^{4}$ Department of Pathology, Faculty of Medicine, University of Malaya, 50603 Kuala Lumpur, Malaysia. ${ }^{5}$ Centre for Applied Physics and Radiation Technologies, Sunway University, Jalan University, 46150 Petaling Jaya, Malaysia. ${ }^{6}$ Department of Physics, University of Surrey, Guildford GU2 7XH, UK.

Received: 30 July 2021 Accepted: 5 January 2022

Published online: 29 January 2022

\section{References}

1. Siegel R, Naishadham D, Jemal A. Cancer statistics, 2012. CA Cancer J Clin. 2012;62(1):10-29. https://doi.org/10.3322/ caac.20138.

2. Cumberbatch MGK, Jubber I, Black PC, Esperto F, Figueroa JD, Kamat AM, Kiemeney L, Lotan Y, Pang K, Silverman DT, Znaor A, Catto JWF. Epidemiology of bladder cancer: a systematic review and contemporary update of risk factors in 2018. Eur Urol. 2018;74:784-95. 
3. Brausi M, Collette L, Kurth K, Van Der Meijden AP, Oosterlinck W, Witjes JA, Newling D, Bouffioux C, Sylvester RJ. Variability in the recurrence rate at first follow-up cystoscopy after TUR in stage Ta T1 transitional cell carcinoma of the bladder: a combined analysis of seven EORTC studies. Eur Urol. 2002;41(5):523-31.

4. Catto JWF, Khetrapal P, Ambler G, Sarpong R, Khan MS, Tan M, Feber A, Dixon S, Goodwin L, Williams NR, McGrath J, Rowe E, Koupparis A, Brew-Graves C, Kelly JD. Robot-assisted radical cystectomy with intracorporeal urinary diversion versus open radical cystectomy (iROC): protocol for a randomised controlled trial with internal feasibility study. BMJ Open. 2018;8(8): e020500.

5. Goossens-Laan CA, Visser O, Hulshof MCCM, Wouters MW, Bosch JLHR, Coebergh J-WW, Kil PJM. Survival after treatment for carcinoma invading bladder muscle: a Dutch population-based study on the impact of hospital volume. BJU Int. 2012;110(2):226-32. https://doi.org/10.1111/j.1464-410X.2011.10694.x.

6. Stenzl A, Cowan NC, De Santis M, Kuczyk MA, Merseburger AS, Ribal MJ, Sherif A, Witjes JA. Treatment of muscleinvasive and metastatic bladder cancer: update of the EAU guidelines. Eur Urol. 2011;59(6):1009-18.

7. Ploussard G, Daneshmand S, Efstathiou JA, Herr HW, James ND, Rödel CM, Shariat SF, Shipley WU, Sternberg CN, Thalmann GN, Kassouf W. Critical analysis of bladder sparing with trimodal therapy in muscle-invasive bladder cancer: a systematic review. Eur Urol. 2014;66:120-37.

8. Baenke F, Peck B, Miess H, Schulze A. Hooked on fat: the role of lipid synthesis in cancer metabolism and tumour development. DMM. 2013;6:1353-63.

9. Greife A, Tukova J, Steinhoff C, Scott SD, Schulz WA, Hatina J. Establishment and characterization of a bladder cancer cell line with enhanced doxorubicin resistance by mevalonate pathway activation. Tumor Biol. 2015;36(5):3293-300.

10. Warita K, Warita T, Beckwitt CH, Schurdak ME, Vazquez A, Wells A, Oltvai ZN. Statin-induced mevalonate pathway inhibition attenuates the growth of mesenchymal-like cancer cells that lack functional E-cadherin mediated cell cohesion. Sci Rep. 2014;4:7593.

11. Ahmadi Y, Karimian R, Panahi Y. Effects of statins on the chemoresistance-the antagonistic drug-drug interactions versus the anti-cancer effects. Biomed Pharmacother. 2018;108:1856-65.

12. Said NABM, Gould CM, Lackovic K, Simpson KJ, Williams ED. Whole-genome multiparametric screening to identify modulators of epithelial-to-mesenchymal transition. Assay Drug Dev Technol. 2014;12(7):385-94.

13. Dyrskjøt L, Thykjaer T, Kruhøffer M, Jensen $J$, Marcussen N, Hamilton-Dutoit S, Wolf H, Ørntoft TF. Identifying distinct classes of bladder carcinoma using microarrays. Nat Genet. 2003;33(1):90-6.

14. Tüzmen ş, Hostetter G, Watanabe A, Ekmekçi C, Carrigan PE, Shechter I, Kallioniemi O, Miller LJ, Mousses S. Characterization of farnesyl diphosphate farnesyl transferase 1 (FDFT1) expression in cancer. Per Med. 2019;16(1):51-65.

15. Ha NT, Lee CH. Roles of farnesyl-diphosphate farnesyltransferase 1 in tumour and tumour microenvironments. Cells. 2020;9(11):2352.

16. Brusselmans K, Timmermans L, Van De Sande T, Van Veldhoven PP, Guan G, Shechter I, Claessens F, Verhoeven G, Swinnen JV. Squalene synthase, a determinant of raft-associated cholesterol and modulator of cancer cell proliferation. J Biol Chem. 2007;282(26):18777-85.

17. Garnett MJ, Edelman EJ, Heidorn SJ, Greenman CD, Dastur A, Lau KW, Greninger P, Thompson IR, Luo X, Soares J, Liu Q, lorio F, Surdez D, Chen L, Milano RJ, Bignell GR, Tam AT, Davies H, Stevenson JA, Barthorpe S, Lutz SR, Kogera F, Lawrence K, McLaren-Douglas A, Mitropoulos X, Mironenko T, Thi H, Richardson L, Zhou W, Jewitt F, Zhang T, O'Brien P, Boisvert JL, Price S, Hur W, Yang W, Deng X, Butler A, Choi HG, Chang JW, Baselga J, Stamenkovic I, Engelman JA, Sharma SV, Delattre O, Saez-Rodriguez J, Gray NS, Settleman J, Futreal PA, Haber DA, Stratton MR, Ramaswamy S, McDermott $\mathrm{U}$, Benes $\mathrm{CH}$. Systematic identification of genomic markers of drug sensitivity in cancer cells. Nature. 2012:483(7391):570-5.

18. Jen CP, Te Huang C, Chen YS, Kuo CT, Wang HC. Diagnosis of human bladder cancer cells at different stages using multispectral imaging microscopy. IEEE J Sel Top Quantum Electron. 2014;20(3):81-8.

19. Tiguert R, Fradet Y. New diagnostic and prognostic tools in bladder cancer. Curr Opin Urol. 2002;12:239-43.

20. De Jong BWD, Schut TCB, Maquelin K, Van Der Kwast T, Bangma CH, Kok DJ, Puppels GJ. Discrimination between nontumor bladder tissue and tumor by Raman spectroscopy. Anal Chem. 2006;78(22):7761-9.

21. D'Hallewin MA, Bezdetnaya L, Guillemin F. Fluorescence detection of bladder cancer: a review. Eur Urol. 2002;42(5):417-25.

22. Wilkinson BA, Smallwood RH, Keshtar A, Lee JA, Hamdy FC. Electrical impedance spectroscopy and the diagnosis of bladder pathology: a pilot study. J Urol. 2002;168(41):1563-7.

23. Bernhardt TM, Rapp-Bernhardt U. Invited update: virtual cystoscopy of the bladder based on CT and MRI data. Abdom Imaging. 2001;26:325-32. https://doi.org/10.1007/s002610000168.

24. Little B. Non-invasive methods of bladder cancer detection. Int Urol Nephrol. 2003;35:331-43. https://doi.org/10. 1023/B:UROL.0000022917.82043.0a.

25. Sözen S, Eskicorabci S, Özen H. Urinary markers for urothelial cancer. BJU Int. 2003;92:531-3.

26. Draga ROP, Grimbergen MCM, Vijverberg PLM, Swol CFPV, Jonges TGN, Kummer JA, Ruud Bosch JLH. In vivo bladder cancer diagnosis by high-volume Raman spectroscopy. Anal Chem. 2010;82(14):5993-9.

27. Sloan FA, Yashkin AP, Akushevich I, Inman BA. The cost to medicare of bladder cancer care. Eur Urol Oncol. 2020;3(4):515-22.

28. Antoni S, Ferlay J, Soerjomataram I, Znaor A, Jemal A, Bray F. Bladder cancer incidence and mortality: a global overview and recent trends. Eur Urol. 2017;71(1):96-108.

29. Huttanus HM, Vu T, Guruli G, Tracey A, Carswell W, Said N, Du P, Parkinson BG, Orlando G, Robertson JL, Senger RS. Raman chemometric urinalysis (Rametrix) as a screen for bladder cancer. PLoS ONE. 2020;15(8): e0237070.

30. Compérat EM, Burger M, Gontero P, Mostafid AH, Palou J, Rouprêt M, van Rhijn BWG, Shariat SF, Sylvester RJ, Zigeuner R, Babjuk M. Grading of urothelial carcinoma and the new "World Health Organisation classification of tumours of the urinary system and male genital organs 2016." Eur Urol Focus. 2019;5:457-66.

31. Winquist E, Kirchner TS, Segal R, Chin J, Lukka H. Neoadjuvant chemotherapy for transitional cell carcinoma of the bladder: a systematic review and meta-analysis. J Urol. 2004;171:561-9. 
32. Audenet F, Sfakianos JP, Waingankar N, Ruel NH, Galsky MD, Yuh BE, Gin GE. A delay $\geq 8$ weeks to neoadjuvant chemotherapy before radical cystectomy increases the risk of upstaging. Urol Oncol Semin Orig Investig. 2019;37(2):116-22.

33. Massari F, Santoni M, Ciccarese C, Brunelli M, Conti A, Santini D, Montironi R, Cascinu S, Tortora G. Emerging concepts on drug resistance in bladder cancer: implications for future strategies. Crit Rev Oncol Hematol. 2015;96:81-90.

34. Pond GR, Bellmunt J, Fougeray R, Choueiri TK, Qu AQ, Niegisch G, Albers P, Di Lorenzo G, Salhi Y, Galsky MD, Agarwal $\mathrm{N}$, Necchi A, Sonpavde G. Impact of response to prior chemotherapy in patients with advanced urothelial carcinoma receiving second-line therapy: implications for trial design. Clin Genitourin Cancer. 2013;11(4):495-500.

35. Thurnher M, Nussbaumer O, Gruenbacher G. Novel aspects of mevalonate pathway inhibitors as antitumor agents. Clin Cancer Res. 2012;18:3524-31.

36. Rudney H, Sexton RC. Regulation of cholesterol biosynthesis. Annu Rev Nutr. 1986;6(1):245-72. https://doi.org/10. 1146/annurev.nu.06.070186.001333.

37. Grouleff J, Irudayam SJ, Skeby KK, Schiøtt B. The influence of cholesterol on membrane protein structure, function, and dynamics studied by molecular dynamics simulations. Biochim Biophys Acta Biomembr. 2015;1848:1783-95.

38. Cruz PMR, Mo H, McConathy WJ, Sabnis N, Lacko AG. The role of cholesterol metabolism and cholesterol transport in carcinogenesis: a review of scientific findings, relevant to future cancer therapeutics. Front Pharmacol. 2013;4:119.

39. Murai T. Cholesterol lowering: role in cancer prevention and treatment. Biol Chem. 2015;396:1-11.

40. Long J, Zhang C-J, Zhu N, Du K, Yin Y-F, Tan X, Liao D-F, Qin L. Lipid metabolism and carcinogenesis, cancer development. Am J Cancer Res. 2018;8(5):778-91.

41. Gorin A, Gabitova L, Astsaturov I. Regulation of cholesterol biosynthesis and cancer signaling. Curr Opin Pharmacol. 2012;12:710-6.

42. Kuzu OF, Noory MA, Robertson GP. The role of cholesterol in cancer. Can Res. 2016;76:2063-70.

43. Desbats MA, Giacomini I, Prayer-Galetti T, Montopoli M. Metabolic plasticity in chemotherapy resistance. Front Oncol. 2020;10:281.

44. Huang B, Song BL, Xu C. Cholesterol metabolism in cancer: mechanisms and therapeutic opportunities. Nat Metab. 2020;2:132-41. https://doi.org/10.1038/s42255-020-0174-0.

45. Miettinen TA, Kesäniemi YA. Cholesterol absorption: regulation of cholesterol synthesis and elimination and withinpopulation variations of serum cholesterol levels. Am J Clin Nutr. 1989;49(4):629-35.

46. Goldstein JL, Brown MS. The LDL receptor. Arterioscler Thromb Vasc Biol. 2009;29:431-8.

47. Luo J, Jiang LY, Yang H, Song BL. Intracellular cholesterol transport by sterol transfer proteins at membrane contact sites. Trends Biochem Sci. 2019;44:273-92.

48. Wang YJ, Bian Y, Luo J, Lu M, Xiong Y, Guo SY, Yin HY, Lin X, Li Q, Chang CCY, Chang TY, Li BL, Song BL. Cholesterol and fatty acids regulate cysteine ubiquitylation of ACAT2 through competitive oxidation. Nat Cell Biol. 2017;19(7):808-19.

49. Brown MS, Radhakrishnan A, Goldstein JL. Retrospective on cholesterol homeostasis: the central role of scap. Annu Rev Biochem. 2018;87:783-807.

50. Wang B, Tontonoz P. Liver $X$ receptors in lipid signalling and membrane homeostasis. Nat Rev Endocrinol. 2018;14:452-63.

51. Lewis CA, Brault C, Peck B, Bensaad K, Griffiths B, Mitter R, Chakravarty P, East P, Dankworth B, Alibhai D, Harris AL, Schulze A. SREBP maintains lipid biosynthesis and viability of cancer cells under lipid- and oxygen-deprived conditions and defines a gene signature associated with poor survival in glioblastoma multiforme. Oncogene. 2015;34(40):5128-40.

52. Stopsack KH, Gerke TA, Andrén O, Andersson SO, Giovannucci EL, Mucci LA, Rider JR. Cholesterol uptake and regulation in high-grade and lethal prostate cancers. Carcinogenesis. 2017;38(8):806-11.

53. Kim W-Y. Therapeutic targeting of lipid synthesis metabolism for selective elimination of cancer stem cells. Arch Pharm Res. 2019:42(1):25-39. https://doi.org/10.1007/s12272-018-1098-z.

54. Kaymak I, Maier CR, Schmitz W, Campbell AD, Dankworth B, Ade CP, Walz S, Paauwe M, Kalogirou C, Marouf H, Rosenfeldt MT, Gay DM, McGregor GH, Sansom OJ, Schulze A. Mevalonate pathway provides ubiquinone to maintain pyrimidine synthesis and survival in p53-deficient cancer cells exposed to metabolic stress. Cancer Res. 2020;80(2):189-203.

55. Garcia-Bermudez J, Baudrier L, Bayraktar EC, Shen Y, La K, Guarecuco R, Yucel B, Fiore D, Tavora B, Freinkman E, Chan SH, Lewis C, Min W, Inghirami G, Sabatini DM, Birsoy K. Squalene accumulation in cholesterol auxotrophic lymphomas prevents oxidative cell death. Nature. 2019;567(7746):118-22.

56. Porstmann T, Griffiths B, Chung YL, Delpuech O, Griffiths JR, Downward J, Schulze A. PKB/Akt induces transcription of enzymes involved in cholesterol and fatty acid biosynthesis via activation of SREBP. Oncogene. 2005;24(43):6465-81.

57. Wang X, Huang Z, Wu Q, Prager BC, Mack SC, Yang K, Kim LJY, Gimple RC, Shi Y, Lai S, Xie Q, Miller TE, Hubert CG, Song A, Dong Z, Zhou W, Fang X, Zhu Z, Mahadev V, Bao S, Rich JN. MYC-regulated mevalonate metabolism maintains brain tumor-initiating cells. Cancer Res. 2017;77(18):4947-60.

58. Bakiri L, Hamacher R, Graña O, Guío-Carrión A, Campos-Olivas R, Martinez L, Dienes HP, Thomsen MK, Hasenfuss SC, Wagner EF. Liver carcinogenesis by FOS-dependent inflammation and cholesterol dysregulation. J Exp Med. 2017;214(5):1387-409

59. Yue S, Li J, Lee SY, Lee HJ, Shao T, Song B, Cheng L, Masterson TA, Liu X, Ratliff TL, Cheng JX. Cholesteryl ester accumulation induced by PTEN loss and PI3K/AKT activation underlies human prostate cancer aggressiveness. Cell Metab. 2014;19(3):393-406.

60. Liu D, Wong CC, Fu L, Chen H, Zhao L, Li C, Zhou Y, Zhang Y, Xu W, Yang Y, Wu B, Cheng G, Lai PBS, Wong N, Sung JJY, Yu J. Squalene epoxidase drives NAFLD-induced hepatocellular carcinoma and is a pharmaceutical target. Sci Transl Med. 2018;10(437):9840.

61. Montero J, Morales A, Llacuna L, Lluis JM, Terrones O, Basañez G, Antonsson B, Prieto J, García-Ruiz C, Colell A, Fernández-Checa JC. Mitochondrial cholesterol contributes to chemotherapy resistance in hepatocellular carcinoma. Cancer Res. 2008;68(13):5246-56. 
62. Wang SF, Chou YC, Mazumder N, Kao FJ, Nagy LD, Guengerich FP, et al. 7-Ketocholesterol induces P-glycoprotein through PI3K/mTOR signaling in hepatoma cells. Biochem Pharmacol. 2013;86(4):548-60.

63. Kim S, Lee $M$, Dhanasekaran DN, Song YS. Activation of $L X R a / \beta$ by cholesterol in malignant ascites promotes chemoresistance in ovarian cancer. BMC Cancer. 2018;18(1):1232.

64. Wu Y, Si R, Tang H, He Z, Zhu H, Wang L, et al. Cholesterol reduces the sensitivity to platinum-based chemotherapy via upregulating ABCG2 in lung adenocarcinoma. Biochem Biophys Res Commun. 2015;457(4):614-20.

65. Wang $\mathrm{C}, \mathrm{He} \mathrm{H}$, Fang W. Oncogenic roles of the cholesterol metabolite 25-hydroxycholesterol in bladder cancer. Oncol Lett. 2020;19(6):3671-6.

66. Shechter I, Conrad DG, Hart I, Berger RC, McKenzie TL, Bleskan J, Patterson D. Localization of the squalene synthase gene (FDFT1) to human chromosome 8p22-p23.1. Genomics. 1994;20(1):116-8.

67. Barretina J, Caponigro G, Stransky N, Venkatesan K, Margolin AA, Kim S, Wilson CJ, Lehár J, Kryukov GV, Sonkin D, Reddy A, Liu M, Murray L, Berger MF, Monahan JE, Morais P, Meltzer J, Korejwa A, Jané-Valbuena J, Mapa FA, Thibault J, Bric-Furlong E, Raman P, Shipway A, Engels IH, Cheng J, Yu GK, Yu J, Aspesi P, De Silva M, Jagtap K, Jones MD, Wang L, Hatton C, Palescandolo E, Gupta S, Mahan S, Sougnez C, Onofrio RC, Liefeld T, MacConaill L, Winckler W, Reich M, Li N, Mesirov JP, Gabriel SB, Getz G, Ardlie K, Chan V, Myer VE, Weber BL, Porter J, Warmuth M, Finan P, Harris JL, Meyerson M, Golub TR, Morrissey MP, Sellers WR, Schlegel R, Garraway LA. The Cancer Cell Line Encyclopedia enables predictive modelling of anticancer drug sensitivity. Nature. 2012;483(7391):603-7.

68. Shimokuni T, Tanimoto K, Hiyama K, Otani K, Ohtaki M, Hihara J, Yoshida K, Noguchi T, Kawahara K, Natsugoe S, Aikou T, Okazaki Y, Hayashizaki Y, Sato Y, Todo S, Hiyama E, Nishiyama M. Chemosensitivity prediction in esophageal squamous cell carcinoma: Novel marker genes and efficacy-prediction formulae using their expression data. Int J Oncol. 2006;28(5):1153-62.

69. Choo-Smith L-P, Edwards HGM, Endtz HP, Kros JM, Heule F, Barr H, Robinson JS, Bruining HA, Puppels GJ. Medical applications of Raman spectroscopy: from proof of principle to clinical implementation. Biopolymers. 2002;67(1):19. https://doi.org/10.1002/bip.10064.

70. Ryzhikova E, Ralbovsky NM, Sikirzhytski V, Kazakov O, Halamkova L, Quinn J, Zimmerman EA, Lednev IK. Raman spectroscopy and machine learning for biomedical applications: Alzheimer's disease diagnosis based on the analysis of cerebrospinal fluid. Spectrochim Acta A Mol Biomol Spectrosc. 2021;248: 119188.

71. Tabbasum S, Majeed MI, Nawaz H, Rashid N, Tahira M, Mohsin A, Arif A, ul Haq A, Saleem M, Dastgir G, Batool F. Surface-enhanced Raman spectroscopy for comparison of serum samples of typhoid and tuberculosis patients of different stages. Photodiagn Photodyn Ther. 2021;35: 102426.

72. Chaichi A, Prasad A, Gartia MR. Raman spectroscopy and microscopy applications in cardiovascular diseases: from molecules to organs. Biosensors. 2018;8(4):107.

73. Andrews DL. Rayleigh scattering and Raman effect, theory. In: Encyclopedia of spectroscopy and spectrometry. Amsterdam: Elsevier; 2017. p. 924-30.

74. Pask HM, Piper JA. Raman lasers. In: Jin J, editor. Handbook of solid-state lasers: materials, systems and applications. Cambridge: Woodhead Publishing; 2013. p. 493-524.

75. Ur Rehman I, Movasaghi Z, Rehman S. Vibrational spectroscopy for tissue analysis. Boca Raton: CRC Press; 2012. p. $1-303$.

76. Kagi H, Fukura S, Odake S, Mizukami T. Factors determining the stability, resolution, and precision of a conventional Raman spectrometer. Appl Spectrosc. 2006;60(8):946-50.

77. Ivleva NP, Kubryk P, Niessner R. Raman microspectroscopy, surface-enhanced Raman scattering microspectroscopy, and stable-isotope Raman microspectroscopy for biofilm characterization. Anal Bioanal Chem. 2017:409(18):435375. https://doi.org/10.1007/s00216-017-0303-0.

78. Pudney PD, Bonnist EY, Caspers PJ, Gorce JP, Marriot C, Puppels GJ, Singleton S, van der Wolf MJ. A new in vivo Raman probe for enhanced applicability to the body. Appl Spectrosc. 2012;66(8):882-91.

79. Kujdowicz M, Placha W, Mech B, Chrabaszcz K, Okoń K, Malek K. In vitro spectroscopy-based profiling of urothelial carcinoma: a Fourier transform infrared and Raman imaging study. Cancers. 2021;13(1):123.

80. Zhang Y, Lai X, Zeng Q, Li L, Lin L, Li S, Liu Z, Su C, Qi M, Guo Z. Classifying low-grade and high-grade bladder cancer using label-free serum surface-enhanced Raman spectroscopy and support vector machine. Laser Phys. 2018;28(3): 035603. https://doi.org/10.1088/1555-6611/aa9d6d.

81. Kong C, Zhu S, Chen S, Qian W, Xu W, Cui X, Zhang Z. Identifying non-muscle-invasive and muscle-invasive bladder cancer based on blood serum surface-enhanced Raman spectroscopy. Biomed Opt Express. 2019;10(7):3533-44.

82. Chen H, Li X, Broderick N, Liu Y, Zhou Y, Han J, Xu W. Identification and characterization of bladder cancer by lowresolution fiber-optic Raman spectroscopy. J Biophotonics. 2018;1 1(9): e201800016. https://doi.org/10.1002/jbio. 201800016.

83. Draga ROP, Grimbergen MCM, Vijverberg PLM, van Swol CFP, Jonges TGN, Kummer JA, Bosch JLHR. In vivo bladder cancer diagnosis by high-volume Raman spectroscopy. Anal Chem. 2010;82(14):5993-9. https://doi.org/10.1021/ ac100448p.

84. Shapiro A, Gofrit ON, Pizov G, Cohen JK, Maier J. Raman molecular imaging: a novel spectroscopic technique for diagnosis of bladder cancer in urine specimens. Eur Urol. 2011;59(1):106-12.

85. Lalkhen AG, McCluskey A. Clinical tests: sensitivity and specificity. Contin Educ Anaesth Crit Care Pain. 2008;8(6):221-3.

86. Canetta E, Riches A, Borger E, Herrington S, Dholakia K, Adya AK. Discrimination of bladder cancer cells from normal urothelial cells with high specificity and sensitivity: combined application of atomic force microscopy and modulated Raman spectroscopy. Acta Biomater. 2014;10(5):2043-55.

87. Li S, Li L, Zeng Q, Zhang Y, Guo Z, Liu Z, Jin M, Su C, Lin L, Xu J, Liu S. Characterization and noninvasive diagnosis of bladder cancer with serum surface enhanced Raman spectroscopy and genetic algorithms. Sci Rep. 2015;5(1):1-7.

88. Bovenkamp D, Sentosa R, Rank E, Erkkilä MT, Placzek F, Püls J, Drexler W, Leitgeb RA, Garstka N, Shariat SF, Stiebing C, Schie IW, Popp J, Andreana M, Unterhuber A. Combination of high-resolution optical coherence tomography and Raman spectroscopy for improved staging and grading in bladder cancer. Appl Sci. 2018;8(12):2371. 
89. Chun HJ, Weiss TL, Devarenne TP, Laane J. Vibrational spectra and DFT calculations of squalene. J Mol Struct. 2013;1032:203-6.

90. Hall DW, Marshall SN, Gordon KC, Killeen DP. Rapid quantitative determination of squalene in shark liver oils by Raman and IR spectroscopy. Lipids. 2016;51(1):139-47. https://doi.org/10.1007/s11745-015-4097-6.

91. Czamara K, Majzner K, Pacia MZ, Kochan K, Kaczor A, Baranska M. Raman spectroscopy of lipids: a review. J Raman Spectrosc. 2015;46(1):4-20. https://doi.org/10.1002/jrs.4607.

92. Pinto A, Silveira L Jr, Teixeira F, Tavares PT, Amaro Z, Augusto P. Discriminating neoplastic and normal brain tissues in vitro through Raman spectroscopy: a principal components analysis classification model. Photomed Laser Surg. 2013;31(12):595-604. https://doi.org/10.1089/pho.2012.3460.

93. Weinmann P, Jouan M, Quy Dao N, Lacroix B, Groiselle C, Bonte JP, Luc G. Quantitative analysis of cholesterol and cholesteryl esters in human atherosclerotic plaques using near-infrared Raman spectroscopy. Atherosclerosis. 1998;140(1):81-8.

94. Hanlon EB, Manoharan R, Koo T-W, Shafer KE, Motz JT, Fitzmaurice M, Kramer JR, Itzkan I, Dasari RR, Feld MS. Prospects for in vivo Raman spectroscopy. Phys Med Biol. 2000;45(2):R1. https://doi.org/10.1088/0031-9155/45/2/201.

95. Jamieson LE, Li A, Faulds K, Graham D. Ratiometric analysis using Raman spectroscopy as a powerful predictor of structural properties of fatty acids. R Soc Open Sci. 2018;5(12): 181483. https://doi.org/10.1098/rsos.181483.

\section{Publisher's Note}

Springer Nature remains neutral with regard to jurisdictional claims in published maps and institutional affiliations.

- fast, convenient online submission

- thorough peer review by experienced researchers in your field

- rapid publication on acceptance

- support for research data, including large and complex data types

- gold Open Access which fosters wider collaboration and increased citations

- maximum visibility for your research: over $100 \mathrm{M}$ website views per year

At BMC, research is always in progress.

Learn more biomedcentral.com/submissions 